\title{
Infrastructural Development as A Means of Attracting Foreign Direct Investment for Economic Development in Nigeria
}

\author{
Eze Friday John \\ Federal Polytechnic ,Kaura \\ Namoda, Zamfara State, Nigeria
}

\author{
Ndubuisi-Okolo purity.U. \\ Nnamdi Azikiwe University, \\ Awka, Anambra State, Nigeria
}

\author{
Anekwe Rita Ifeoma \\ Nnamdi Azikiwe University, \\ Awka, Nigeria
}

\begin{abstract}
Foreign direct investment is a key ingredient of development that most nations of the world seek to attract to boost economic growth and development.

power, transportation and other areas of infrastructure be maintained and carried to the next level by the incoming administration.
\end{abstract} This paper sought to examine the place of infrastructure in attracting foreign direct investment, which is considered an instrument of development. The paper adopted a conceptual approach to its analysis of data obtained from secondary sources. Researchers vary in their opinions regarding the impact of foreign direct investment on the economy of a nation. However, it became clear that FDI cannot be wished away with regard to its contribution to the economy; otherwise the effort to attract foreign capital as made by many nations today, especially the developing ones like Nigeria, would not have been observed. We discovered that the inflow of FDI to Nigeria has been relatively on the increase, and that Nigeria tops the list in terms of FDI inflow into the whole of Africa. Equally, Nigeria as a developing nation has been making series of efforts in terms of state policies and programmes toward attracting foreign investment. Such efforts include the liberalization of the economy, setting up of the Nigerian Investment Promotion Commission, and the privatization and reform programmes of successive governments beginning from the 1980s. It also became clear that Nigeria's economy benefits from foreign direct investment. In order to sustain the momentum of FDI inflow with its attendant contribution to development, we recommend, among others, that the current reform agenda especially in the

Key words: Foreign direct investment, Infrastructure development, economic growth, economic development

\section{INTRODUCTION}

\subsection{Background of the Study}

Developing infrastructure is a key issue in the development of any nation. This is because not only that it makes life easier by adding to the quality of life people live but also because it enables seamless performance of business/economic activities, which further increase the peoples living standard. Foreign Direct Investment (FDI) is one factor that adds to the quantum of economic activities that enable economic growth and development. FDI is one of the three forms of international capital flows: the others are portfolio investment and other such as bank loans. The inflow of foreign capital is assumed to be beneficial to the receiving or host country in the sense that it contributes to local capital, managerial expertise and technological improvement. Contessi \& Weinberger (2011) however observe that FDI, being an investor's acquisition of long term influence in the management of a firm in another country, raises concern in the developed world. Countries that export capital are concerned that capital leaving their countries might 
hurt domestic investment; while in the receiving countries their politicians and workers fear foreign domination of ownership of domestic firms. On the other hand, they maintain that emerging, transition and developing countries usually welcome FDI believing that investment through FDI will bring additional capital, managerial expertise and technology transfer. On the flip side, other researches indicate that FDI hurts local firms through competition brought by superior resource power of the multinational enterprises that usually make such investments in the host country.

Studies on the relationship between FDI and economic development reveal that the effects of FDI are complex. When viewed from a macro perspective, FDI is seen to generate employment, high productivity, competitiveness, and technology spillovers (Denisia, 2010; Sichei \& Kinyondo, 2012). Sichei and Kinyondo (2012) observe that Africa's inability to attract FDI is troubling because it presents a potential solution to the continent's growth and development challenges. They stress further that FDI provides the needed capital for investment, brings with it employment, managerial skills and technology and at the end accelerates growth and development. Infrastructure development in the national space provides the enabling environment for such investments and to a great extent contributes to the safety of such investment.

The paucity of infrastructure in Nigeria and Africa as a whole is a serious matter hindering the development of the African continent in general and Nigeria in particular. The most important and in fact, most challenging of the infrastructure gap is power. Energy drives development and the quantum of energy supply in Nigeria hardly carries domestic needs not to talk of industrial and commercial needs. The various selfhelp employments such as hair dressing, welding, fashion and designing, to mention a few suffer greatly from inadequate power supply. If this is the lot of micro and small businesses, one would imagine what the big enterprises, especially manufacturing concerns pass through in the face of power problem in the country. Following the issue of power are other vital infrastructure such as effective communication (including internet broadband), transportation (roads are only recently getting better and railways that have been moribund for decades are just coming back to life). Another critical infrastructure deficit is in the area of ports development. The Tincan Island and Apapa ports are simply inadequate to carry the demands of a highly import-dependent and exportaspiring economy like Nigeria. The dredging of Calabar port and the envisaged development of deep sea port in Lagos and Delta states with the attendant easing of ports congestion, are however good omen). The low level of infrastructure development in the country, we conjecture, is a developmental challenge and a factor in deterring investors.

Literature is awash with the concept of the determinants of foreign direct investment which mainly centre on resource endowment and other macro economic variables as the factors encouraging or deterring investors. Among such other factors include: Return on investment, infrastructure development, openness of the economy to trade, political risk, government size, and human capital.

Researches show that the flow of FDI to Africa is less than that going to other individual parts of the globe: Africa's share of global FDI inflows declined from 9.5 per cent in 1970 to 5.3 per cent in 2009. FDI flows in the world have increased dramatically from $\$ 13.3$ billion in 1970 to $\$ 2.1$ trillion in 2007 before declining to $\$ 1.1$ trillion in 2009 due to the global financial crisis in 2008-2009. However, Africa, as a region, has not benefited from the FDI boom since the volume of FDI inflows to the continent is not only low as a share of global FDI but is also on a downward trend for the last three decades as the above figures show (Denisia, 2010, Sichei \& Kinyondo, 2012). They observe that FDI inflows to Africa have been to countries that are classified by the World Bank as oil and mineral dependent including South Africa, Angola, Nigeria, Equatorial Guinea, and Egypt, among others. This phenomenon raises the questions as to whether Africa has been attracting one (asset- or resource-seeking) form of FDI or not. The following facts they present speaks volume in this regard: FDI to Africa has been attracted to countries endowed with natural resources. 24 countries classified by the World Bank as oil- and mineraldependent have, on average, accounted for close to 75 per cent of annual FDI flows to Africa. 10 leading recipients of FDI inflows in 2009 (Angola, Egypt, Nigeria, South Africa, Sudan, Algeria, Libya, Congo, Tunisia, Ghana and Equatorial Guinea) have large mineral and petroleum reserves. 
It is the opinion of this paper that in addition to political and social instability this scenario can be, to a great extent, attributed to the fact that Africa, and Sub-Saharan Africa in particular, has less developed infrastructure. The reason is obvious: any investor would like to invest in an environment with critical infrastructure that would promote business operations. Denisia (2010) agrees much with this by observing that well established and quality infrastructure is an important determinant of FDI inflows. And this cannot be wished away in Africa with a lot of other impediments to development.

\subsection{Statement of the Problem}

The acceleration of economic development is enhanced by the quantum of infrastructure available, which promote activities that enlarge the economy of any nation. Equally, in today's world no nation can develop as a closed system that is not allowing the inflow of resources from outside. This is why the contribution of foreign direct investment in accelerating development especially in a developing country can hardly be over-stressed. In Africa, and in particular the sub-Saharan Africa, there is a general low level of infrastructure development, and from our introductory background we have conjectured that this scenario might be one of the reasons Africa share of Direct Foreign Investment (FDI) is very low. Consequently, it is averred here that this might be contributing in slowing down the economic development of the African continent as a whole and Nigeria in particular. Nigeria as a nation has found out that the low level of infrastructure development is hindering her development and the ability to occupy her place among the committee of nations, despite being the largest economy in Africa. Nigeria, having about 27 percent of Africa's GDP and 76 percent of GDP of the West African sub-region, holds a lot of potential to unlock Africa's development. This cannot happen without adequate infrastructure, including credit market as mentioned by Blonigen \& Piger (2011) and the inflow of appropriate level of foreign capital. Though there are other several factors determining the flow of foreign direct investment, but this paper tries to x-ray the place of infrastructure in attracting foreign direct investment. Government policy direction in attracting foreign direct investment is important and it is necessary to also gauge the extent such policies are yielding the desired result.

\subsection{Objectives of the Study}

This paper, infrastructure development as a means of attracting Foreign Direct Investment for economic development of Nigeria, would address the following specific objectives.

1. To analyze the trend in the flow of FDI to Nigeria.

2. To determine the components of the government's effort in attracting FDI and whether this effort is yielding the desired result.

3. To ascertain the impact FDI has so far had on the economic development of Nigeria.

\subsection{Significance of the study}

This study is envisaged to be of significance to policy makers with regard to the issue of infrastructure development with a view to using it as a platform for attracting further Foreign Direct Investments. It would be a source of inspiration and takeoff point for further research on these economically important issues. Other researchers could also use it as a reference material for their work.

\section{REVIEW OF RELATED LITERATURE}

\subsection{Conceptual Review}

\subsubsection{Meaning of Foreign direct investment}

Foreign direct investment is an important component of economic growth and development for any nation. Its impact is even more relevant in the developing countries yearning for the inflow of capital to finance activities/businesses that promote their development. Foreign direct investment (FDI) according to Sichei \& Kinyondo (2012) entails an investor acquiring substantial controlling interest in a foreign firm or sets up a subsidiary in a foreign country. FDI has been described by Kozenkow (2014) as a company's physical investment into building a plant in another country, acquisition of a foreign firm or investment in a joint venture or strategic alliance with a foreign company in its local market. According them, global foreign investment flows have exceeded $\$ 1$ trillion in the 21 st century from $\$ 14$ billion in the 1970 s as given by the United Nations Conference on Trade and Development. These investments impact the host country and the home country of the investing business. Small businesses experience the effects of FDI by hosting foreign companies in their local markets or by investing internationally. 
An overview of the typology of FDI would reveal a number of categorizations. There are three types of FDI. The first type is called market-seeking (horizontal) FDI, where investor's purpose is to serve local markets. The reason for market-seeking FDI is market size and market growth. The second type of FDI is asset-seeking or resource-seeking FDI and takes place when a company's purpose is to gain access or acquire the resources in the host country which are not available in home country such as raw materials, natural resources or low-cost labour. The third type of FDI is efficiency-seeking FDI, which takes place when the company can gain when there is a common governance of geographically dispersed activities and presence of economies of scope and scale (Demirhan \& Masca, 2008; Sichei \& Kinyondo, 2012).

According to Protsenko (2003), four main definitions of vertical and horizontal FDI have been used in the previous literature. The first definition is based on the motivation of investment. Here, FDI is classified to be vertical or horizontal depending on the motive for affiliate operations. Thus, vertical FDI is conducted in order to benefit from factor price differences between countries (Hanson et al., 2003). The second way to distinguish between the two types of FDI was proposed by Brainard (1993), who uses the term "factor proportion" in order to explain foreign activities of MNE. This methodology is derived from the empirical estimation of international trade flows. The third definition employs the geographical distribution of sales of the foreign affiliate (Brainard, 1993, 1997, and Lankes and Venables, 1997). Finally, Markusen (1995) defines vertical FDI as a geographical separation of the production process by stages, which is very similar to fragmentation

There are two main reasons for firms to go multinational (thus engaging in FDI): to serve a foreign market and to get lower cost inputs. This distinction is used to differentiate between two main types of FDI: horizontal and vertical. Horizontal FDI refers to the foreign manufacturing of products and services roughly similar to those the firm produces in its home market. This type of FDI is called "horizontal" because the multinational duplicates the same activities in different countries. Horizontal FDI arises because it is too costly to serve the foreign market by exports due to transportation costs or trade barriers. Vertical FDI refers to those multinationals that fragment production process geographically. It is called "vertical" because MNE separates the production chain vertically by outsourcing some production stages abroad. The basic idea behind the analysis of this type of FDI is that a production process consists of multiple stages with different input requirements. If input prices vary across countries, it becomes profitable for the firm to split the production chain (Protsenko 2003).

He further highlights that vertical FDI "consists of two groups: backward and forward vertical FDI. In case of backward FDI a multinational enterprise establishes its own supplier of input goods which delivers inputs to the parent company. Conducting forward FDI, the firm builds up a foreign affiliate, which draws inputs from the parent company for own production, thus staying after the parent in the production chain" Protsenko 2003: 4).

On another note he contends that a clear separation between horizontal and vertical FDI is not possible, because in case of horizontal FDI affiliates draw some headquarter services from the parent company, even when the firm duplicates the same production activity in several countries. Thus, each horizontal MNE has some vertical traits. Closely related to the term vertical FDI is the literature on outsourcing and fragmentation. These terms are more general and include often the geographical separation of production that takes place outside the firm. Furthermore, different prominent researchers refer to geographical separation of production in different ways. Feenstra (1998) calls it "disintegration of production", Krugman (1996) prefers "slicing the value chain" and Leamer (1996) refers to it as "delocalisation".

\section{Infrastructure and development in Nigeria}

Akinwale (2010) outlines the major components of infrastructure to include the following:

1. Energy infrastructure: electricity, gas and petroleum pipelines;

2. Transportation infrastructure: surface roads, rail system, ports and aviation.

3. Water infrastructure: piped water and irrigation.

4. Communication infrastructure: mass media, internet, phones, and postal services

5. Health infrastructure: primary, secondary and tertiary health care services 
6. Education infrastructure: all categories of schools and higher institutions.

The Infrastructure Fund of the Nigeria Sovereign Investment Authority (NSIA) in its Investment Policy Statement has it that the Fund will invest in infrastructure projects in sectors which have the potential to contribute to the growth and diversification of the Nigerian economy, create jobs within Nigeria and where possible attract foreign investment. One of the objectives of the Nigeria Sovereign Investment Authority is to enhance the development of the Nigerian infrastructure sector. The
Act establishing the Authority provides for the establishment and management of an infrastructure fund by the NSIA. The Infrastructure Fund as one of the three funds of the Authority seeks to make a positive financial return on its investments in the infrastructure sector in Nigeria. It also aims to attract and support foreign investment and enable growth. This is obviously in realization of the fact that without infrastructure, Nigeria's development would be a mirage.

The following table depicts the deplorable state of infrastructure in Nigeria over the years.

Table 1: Selected data on infrastructure in Nigeria compared to other countries

\begin{tabular}{|c|c|c|c|c|c|}
\hline \multirow[b]{2}{*}{ Selected data on infrastructure } & \multicolumn{5}{|c|}{ Countries } \\
\hline & Nigeria & $\begin{array}{l}\text { South } \\
\text { Africa }\end{array}$ & SSA & LIC & HIC \\
\hline $\begin{array}{l}\text { Electric power consumption } \mathrm{kW} \text { per capita } \\
(2001)\end{array}$ & 82 & 3,793 & 456 & 317 & 8,421 \\
\hline $\begin{array}{l}\text { Road-to-population ratio } 1000 \mathrm{~km} \text { per million } \\
\text { people (1995-2001) }\end{array}$ & 1.1 & 8.5 & 2.6 & - & - \\
\hline $\begin{array}{l}\text { Paved primary roads - percent of roads (1995- } \\
\text { 2001) }\end{array}$ & 30.9 & 20.3 & 13.5 & 16 & 92.9 \\
\hline Telephone - Mainlines per 1000 people (2002) & 6 & 107 & 15 & 28 & 585 \\
\hline $\begin{array}{l}\text { Access to sanitation - percent of population } \\
(2000)\end{array}$ & 54 & 87 & 54 & 43 & - \\
\hline $\begin{array}{l}\text { Access to safe water - percent of population } \\
(2000)\end{array}$ & 62 & 86 & 58 & 76 & - \\
\hline
\end{tabular}

Keys: SSA = sub-Saharan Africa; LIC = Low income countries; HIC $=$ High income countries Source: Akinwale, A. A. (2010)

The above figures depict the situation as at 2010. It is our belief that based on the efforts made between 2010 and now in the area of infrastructure at least a modest progress would have been made. This could be a subject for further enquiry.

In the same vein, Ighodaro (2009) opines that the estimated loss to the Nigerian economy as a result of poor state of the roads is about N450 billion yearly. The empirical part of his study shows that no causality was found between road development and economic growth in Nigeria, and his suggestion that government, instead of building new roads should concentrate on maintaining existing ones is obviously flawed. This is because without the expansion of the road network in Nigeria, economic development would generally be hampered.

However, the trend is moving in the positive direction as a lot of progress has been made by the present administration in the areas of road infrastructure, aviation; and with the privatization of the power sector a lot is expected in the economic sphere especially in the manufacturing sector. 


\section{Economic Growth vs. Economic Development}

Kurtishi-Kastrati (2013) tries to show the link between economic growth and economic development. He pointed out that economic development is an all-inclusive concept; its main focus is on economic and social progress. It involves many different aspects that are not easily calculated, such as political freedom, social justice, and environmental reliability. Undoubtedly, all these matters bond together to contribute to an overall high standard of living. However, empirical evidence has sufficiently demonstrated that all these varied elements of economic development associate with economic growth. That is, as a general rule, countries with faster economic growth have more rapid improvement in health and education outcomes, progressively freer political system, increasingly more equitable distribution of wealth, improvement is selfesteem needs, freedom from oppression, and enhanced capacity for environmental management (which are basically the indices of economic development). Therefore, while economic growth does not bring about automatically other aspects of social, institutional and environmental improvements, without economic growth, there is a limited prospect for such achievements that manifest economic development. The most accurate measure of economic growth is the Human Development Index which takes into account the literacy rates and life expectancy. These affect productivity and could lead to economic growth.

\section{Theoretical Background}

FDI inflows are largely a result of a number of factors. According to Blonigen \& Piger (2011), recent papers by Carr, Markusen and Maskus (2001) and Bergstrand and Egger (2007) have developed theoretical models of multinational enterprise's (MNE's) foreign investment decisions that suggest additional possible factors that determine FDI patterns. These studies point out a number of modifications to a standard gravity model (which predicts bilateral trade flows based on the economic sizes (often using GDP measurements) and distance between two units) that may be necessary to accurately explain FDI patterns. First, while gravity variables may adequately capture "horizontal" motivations for FDI, where firms look to replicate their operations in other countries to be more proximate to consumers in those markets, additional controls are necessary to allow for "vertical" motivations of FDI, where firms look for low-cost locations for labor-intensive production. For example, these studies introduce measures of relative labor endowments in the host country with the expectation that countries with relatively high shares of unskilled labor will be attractive locations for MNEs due to lower wages. In addition, these studies show that FDI decisions by MNEs are complex enough that interactions between key variables (e.g., GDP and skilled labor endowments) may be necessary to account for nonlinear effects of these variables on FDI patterns. Head and Ries (2008) differ from these previous studies by modeling FDI as arising from decisions by firms to acquire and control foreign assets (i.e., cross-border mergers and acquisitions), rather than development of new (or Greenfield) plants. Their analysis of FDI patterns highlights the potential role of common culture and language between countries.

The development of theories of the multinational enterprise occurred in three stages (Protsenko, 2003). The first models of multinational firms emerged from the traditional literature on international trade with competitive, constant-return models. Early analysis viewed multinational activities as a part of the theory of capital flows (Caves, 1971). This theory generated clear results that headquarter activities should be placed in capital-abundant countries with subsidiaries in capital-scarce countries. Thus, there was no motive for FDI to occur between identical countries. This was in contrast to empirical observations and led in the next stage to the "new trade theory", which incorporated the idea of increasing returns to scale and imperfect competition to the traditional models. Subsequently, the theory of the multinational enterprise was split into two parts. In the first, the theory of "vertical" FDI emerges, when the firm geographically separates the stages of production. It builds on the theory of capital flows, where direct investment was essentially a foreign production branch. The other strand consists of "horizontal" FDI models, where the firm produces the same goods or services in different locations. In the third stage the new models tried to combine the two branches. The respective theory was called the "Knowledge Capital" model (KC). 
The research has been dominant in the area of factors that determine Foreign Direct Investment, but has not particularly highlighted the issue of infrastructure as a key factor. Rather, resource availability/endowment and other factors occupy the centre stage. These factors have been emphasized elsewhere in this work. So, the common perception is that FDI is largely driven by market size and natural resources. This perception is also consistent with the UNCTAD data three largest recipients of FDI in Africa are South Africa, Nigeria and Angola - all are natural resource rich nations. Nigeria is one of the countries in Western Africa richly endowed with natural resource.

\section{FDI inflow and Development}

Researchers are divided over the implication of foreign direct investment for the economy of the host country. Contessi \& Weinberger (2011) report some of the benefits of FDI to host country as suggested by researchers, first, the transfer of technology that may not be available in the host country, which allows the multi-national investor to be more productive and profitable than local firms. Such transfers are assumed to contribute to the technical progress and growth of the host country (Findlay, 1978). Secondly, a model developed by Rivera-Batiz and Rivera-Batiz (1991) indicates that FDI leads to specialization which ultimately brings about increasing returns. Third, there is the interaction between FDI and investment in human capital Borensztein, De Gregorio, and Lee (1998).

Some other studies highlight reasons why FDI may not accelerate growth: Aitken and Harrison (1999) argue that increased local competition caused by multinationals may crowd out domestic firms; Boyd and Smith (1992) show that FDI distorts resource allocation and slows growth when other distortions are present in the financial sector, prices, or trade. This would imply that FDI does not necessarily contribute to growth, and countries could be harming their economies with provisions that favor FDI.

Dinda (2009) empirically tested the hypothesis that natural resource is one of the determinants of FDI flow to resource-rich poor-African nation like Nigeria. The main objective of the resource-seeking FDI is to extract natural resources and sale in the international market through exporting them.
Automatically these activities may affect foreign exchange and inflation rates in the domestic market which again is a stimulant to FDI flow through raising resource exports. Trade intensity or openness might be crucial policy variable through which all other variables are affected. In this context the study (Dinda, 2009) considered the influence of Nigeria's major trading partners on foreign exchange and inflation rates, as well as FDI flow and economic activities (GDP). The study examined the impact of exogenous factors indicating the major trading partners like the US, the UK, Germany, France and the emerging economies like South Africa, China and India on Nigerian economy. Applying vector error correction model his study suggests that natural resource might be one determinant of FDI flow to Nigeria.

The Nigerian Ambassador to the Netherlands (Dr Mrs. Nimota Nihinlola Akanbi) in 2010, while addressing an Investment Forum of the Nigerian/Netherlands had this to say:

We are aware that on the economic front, the last two years have not been particularly prosperous for most countries including Nigeria. According to the 2010 World Investment Report, Nigeria's Foreign Direct Investment (FDI) in year 2009 dropped to \$6bn as against \$20bn in 2008. However, the global FDI flows witnessed a modest recovery in the first half of 2010.

To realize the target of placing Nigeria among the 20 largest economies in the world by the year 2020, Nigerians and their partners in development would have to work assiduously to increase international investment and make the country a world investment destination. It has been estimated that Nigeria will require 13 Trillion naira or $\$ 200$ billion to achieve the objective (Akanbi, 2010).

The UNCTAD data on world investment report of 2012 highlights the trend of the flow of FDI to various regions of the world. The table below is constructed from the data as reported by Abdel Gawad \& Muramalla (2013). 
Table 2: Relative FDI inflow to some countries in various regions of the world (2011)

\begin{tabular}{|l|l|l|l|}
\hline Region & Country & $\begin{array}{l}\text { FDI inflow } \\
\text { (billions of dollars) }\end{array}$ & $\begin{array}{l}\text { Percent } \\
\text { of } \\
(\%)\end{array}$ \\
\hline Asia & China & 123.985 & 30.4 \\
\hline \multirow{5}{*}{ Europe } & Belgium & 89.142 & - \\
\cline { 2 - 4 } & UK & 53.949 & - \\
\cline { 2 - 4 } & France & 40.945 & - \\
\hline Eurasia & Russian Federation & 52.878 & - \\
\hline Oceania & Australia & 41.317 & - \\
\hline \multirow{2}{*}{ South America } & Brazil & 40.932 & - \\
\cline { 2 - 4 } & Venezuela & 19.554 & - \\
\hline North Africa & Egypt & 66.660 & - \\
\hline West Africa & Nigeria & 5.302 & - \\
\hline West Asia & Saudi Arabia & 6.385 & - \\
\hline
\end{tabular}

Source: Adapted from Abdel Gawad, G. M. \& Muramalla, V. S. R. (2013)

A cursory look at the table shows that China had the largest inflow of FDI within the year in question (2011), followed by Belgium in Europe. In the West African sub-region and in fact, in Africa as a whole Nigeria tops the table. Currently, however, the inflow of Foreign Direct Investment into Nigeria's power sector alone stood at about \$10billion in 2014.

According to Demirhan \& Masca (2008), in the Asian Development Outlook (ADB, 2004), it is stated that in recent years FDI has substantially accelerated as a result of many factors, such as rapid technological progress, emergence of globally integrated production and marketing networks, existence of bilateral investment treaties, recommendations from multilateral development banks, and positive evidence from developing countries that have opened their doors to FDI. Presently many countries have been actively trying to attract foreign investment offering income tax holidays, import duty exemptions and subsidies to foreign firms, as well as measures like market preferences, infrastructures and sometimes even monopoly rights.

\section{Infrastructure, foreign direct investment and development}

The development of infrastructure could be a boost to the inflow of FDI since it has been observed that the inflow to Africa is lower than other regions of the world. Infrastructure that are critical to an emerging economy like Nigeria include, roads, power, transportation, ports development, water, and communication infrastructure that enable faster business start-up and smoother business operations.

Adejugbe (2013) observed that Nigeria is investors' haven going by the abundant resource endowments and given her renowned status as the giant of Africa, but however regrettably, the level (ratio) of FDI coming to Nigeria is abysmally low compared to her potentials. This scenario she attributes to a number of factors including inadequate infrastructure like electricity and good roads. Similarly, Olagunjoye (2010), notes that the poor state of infrastructural facilities has been the malaise of Nigeria's economic development, indicating that the near collapse of public infrastructure in the country is occasioned by many years of neglect by the government as well as lack of maintenance culture and effective and effective planning. The general believe is that without paying the required attention to developing and improving infrastructure sustainable socio-economic development can hardly be achieved. Therefore, investment in and developing infrastructure are key strategies and constitutes the bedrock for sustainable economic growth and development. The obvious explanation is that infrastructure development creates 
the enabling environment to stimulate business and industrial activities. This further promotes productivity, creates jobs, reduces operational costs (consider power and transportation), new venture creation and business opportunities, income generation, wealth creation and poverty reduction generally.

Dinda (2009) observes that the recent surge of FDI inflows to Africa during 2000-2007 followed from positive business environment in the region occasioned by reform framework for FDI. He indicated that many African countries have reformed their economic policy, investment laws and also improving financial system. Notwithstanding the fact that political instability, internal conflict and poor governance still bedevil many countries in Africa, market size is growing in terms of purchasing power in the region with vast population. In most of African nations, FDI inflow rose mainly in the primary sector because of the existence of vast natural resources.

The UNCTAD World Investment Report 2006 shows that FDI inflow to West Africa is mainly dominated by inflow to Nigeria, who received $70 \%$ of the subregional total and $11 \%$ of Africa's total. Out of this Nigeria's oil sector alone receive $90 \%$ of the FDI inflow, consistent with table 2 above, and obviously suggesting a steady increase since 2006. This recent improved performance in FDI inflow to Nigeria calls for the need to investigate the factors that determine its inflow. The study by Dinda (2009) focuses on FDI flow to Nigeria, which is poor in terms of income but rich in natural resources. The study sought to find out the significance of market size, macroeconomic instability, endowment of natural resources and macroeconomic policy like openness in the determination of FDI inflow to poor economy like Nigeria. He indicated that the Nigerian Government adopts several policies to attract FDI in this globalization era. Particularly, the government implemented IMF-monitored liberalization of its economy, welcomes foreign investors in the manufacturing sector, offers incentives for ownership of equity in all industries except key industries like military equipment. The incentives like tax relief are available to investors and concessions for local raw material development. In line with its economic reforms, starting from the 1980s, Nigeria undertook a far reaching privatization programme, which is still on-going; the privatization of the power sector being the most recent and most significant. The changes that support the inflow of FDI started in 1980s with the introduction of several policies like the Structural Adjustment Programme in 1986, Export Processing Zones Decree in 1991, and Investment Promotion Commission in 1995, among others, were adopted by the Nigerian government. However, in the study there is no indication of the influence of infrastructure in attracting the inflow of FDI.

An increase in FDI may be associated with improved economic growth due to the influx of capital and increased tax revenues for the host country. Host countries often try to channel FDI investment into new infrastructure and other projects to boost development. The relationship between FDI and infrastructure can be described as two-way directional: availability of infrastructure can attract FDI, and availability of FDI can promote the development of infrastructure. As a result, because FDI can be used to develop, countries can put in place policies that would attract FDI in order to develop infrastructure. Government investment promotion agency use various marketing strategies, including Diaspora marketing, inspired by the private sector to try to attract FDI.

From his study, Ayanwale (2007) highlights the need for constructive attention to be given to provision of needed infrastructure, especially power generation and distribution, to enhance economic growth. From the results of the study, FDI has a positive but not significant relationship with economic growth. However, the relationships of the separate components of FDI (oil and communications) are both positive and significant. His findings support the consensus that FDI is positively correlated with growth, implying that the inflow of FDI into the economy has positive overall effect on the economy. The contribution of FDI is crucial for countries where incomes and hence domestic savings are particularly low, like Nigeria. External capital is needed for investment to promote economic growth and development. After 1990 the crisis facing poor African nations is a rapid depletion of the official sources: official loans (as share of GNP) to SubSaharan African countries dropped from 6\% in 1990 to $3.8 \%$ in 1998 ; foreign assistance per capita shrunk from US\$35 between 1989 - 1992 to US\$28 between 1993-97 (Dinda, 2009). Limited access to the international capital markets now forced them to rely 
solely on FDI. Especially for Nigeria yearning for development and having been deleted from the official aids list of the international community, the need for FDI appears to be more urgent than ever before.

\section{Government policy initiatives in attracting FDI}

The results of Blonigen, \& Piger's (2011) study reflect little support for government policies to encourage FDI, as there is no robust evidence in their analysis that policy variables controlled by the host country (such as multilateral trade costs, business costs, infrastructure, or political institutions) have an effect on FDI. Exceptions include policies that are often negotiated bilateral agreements, including regional trade agreements, bilateral investment treaties, customs unions, and service agreements in the case of mergers and acquisitions (M\&A). Blonigen, \& Piger (2011).

Ayanwale (2007) however indicates that the adoption of the macroeconomic programmes embedded in the Structural Adjustment Programme (SAP) started the process of gradual increases in the FDI inflow into the country. The macroeconomic details of the SAP are policy measures, which include, one, the inauguration of the Industrial Development Coordination Committee (IDCC), two, the Companies and Allied Matters Act 1990, three, financial liberalization and four, the debt-equity swap programmes. He stated that these programmes were targeted at encouraging FDI inflow and contended that they were largely successful in achieving that aim. However the inflow was not sustained due to the political crises of $1990-$ 1993, during which period the country witnessed a drop in the rate of inflow of FDI, productive activities were disrupted and a regime uncertainty was created, leading to capital flight. Odozi (1995) reports on the factors affecting FDI flow into Nigeria in both the pre and post structural adjustment programme (SAP) eras and found that the macroeconomic policies in place before the SAP were discouraging foreign investors. This policy environment led to the proliferation and growth of parallel markets and sustained capital flight.

In 1995, the government set up the Nigerian Investment Promotion Commission (NIPC) with a view to liberalizing the investment climate. The commission took over from the Industrial Development Coordination Committee (IDCC) as a one-stop agency saddled with the responsibility of facilitating and attracting foreign investors into the country. This resulted in a heightened inflow of FDI into Nigeria especially into the non-oil sectors. Other policy measures that were aimed at attracting FDI into the country include, guided deregulation, Foreign exchange (Monitoring and miscellaneous Provisions) Decree 1999, and the establishment of export processing zones. Currently, FDI inflow into the country has maintained an upward trend movement due, primarily, to the sustained privatization programme. Since 1999, a considerable increase in the inflow of FDI is observable. For example, from the inflow arising from the Global System for mobile communication (GSM) that brought the FDI from $\$ 50$ million by the end of 1999 to $\$ 2.1$ billion by the end of 2002; to the inflow arising from power sector reform that brought the inflow to that sector to about $\$ 10$ billion by the end of 2014 .

In the case of the manufacturing sector FDI inflow, Ayanwale (2007) has this to say:

The increase in manufacturing FDI actually started before 1986. This may be traced to the government's new industrial policy of 1981, which was policy step to encourage manufacturers. Further efforts by the government to create a favourable business environment through the provision of infrastructure facilities, restriction of imports, and the privatization and commercialization programme cncouraged FDI inflow into the sector. As with the oil sector, the inflow into manufacturing witnessed a dramatic upsurge as a result of the NIPC decree of 1995. The subsequent sustained increase in FDI inflow may be attributed to further commercialization and privatization efforts of the government and the creation of the EPZs.

A national effort toward developing infrastructure in Nigeria is set out in the National Sovereign Investment Agency (NSIA). This agency houses the Nigeria Infrastructure Fund (NIF), which focuses entirely on domestic investments in selected infrastructure sectors with a $40 \%$ allocation of Funds. The fund is managed by an in-house team of investment professionals tasked with identifying infrastructure investments, undertaking project development for potential investments and 
recommending projects for investment to the Board. In pursuit of the objectives of the NIF, a Five-Year Infrastructure Investment rolling plan was prepared to provide strategic guidance for NIF investments. An Infrastructure Fund Investment Policy Statement (IPS) was also developed. The IPS provides an investment framework for the NIF, setting out the NIF's investment objectives, risk tolerance and constraints. In accordance with the NSIA Act, each year, a Five-Year Infrastructure Investment rolling plan is to be developed pursuant to such strategies, regulations, policies and guidelines as it may determine to be most effective to achieve its objectives. These objectives include supporting, through investment predicated upon financial returns to NSIA, the development in Nigeria of essential infrastructure such as power generation, distribution and transmission infrastructure, healthcare infrastructure, real estate, agriculture, transport infrastructure, water resources infrastructure, amongst others. This is in order to stimulate the growth and diversification of the Nigerian economy, attract foreign investment and create jobs for Nigerians (NSIA, 2015).

According to the Agency, "Given the pivotal role of power generation and distribution in our economy, particularly in light of the nation's strategic focus on developing its industrial base, NSIA has targeted the power sector as a key focus sector. Our strategy is to invest alongside private investors in attractive projects across the power sector value chain. With the ongoing transformation of Nigeria's power sector through privatization, there are significant opportunities for the NIF to participate in".

An initiative that would be of significance in attracting FDI in the oil and gas sector is the Petroleum Industry Bill that the National Assembly has not been able to pass for a long time now. The Bill if passed would sanitize the oil and gas sector and give foreign investors the assurance or confidence of a conducive investment climate.

Ayanwale's (2007) study concluded that FDI contributes positively to Nigeria's economic growth. The FDI in the communication sector currently has the highest potential to grow the economy, especially the non-oil sector. The FDI in the manufacturing sector has a negative relationship with economic growth, suggesting that the business climate is not healthy enough for the manufacturing sector to thrive and contribute to positive economic growth.

It is also of note that the recent Jonathan administration's industrial policy especially the automobile policy is a significant step towards attracting FDI in a sector Nigerians are spending so much of their income on.

The National Economic Empowerment and Development Strategy (NEEDS) of the Obasanjo administration made FDI attraction an explicit goal for the Government and paid particular attention to drawing investment from wealthy Nigerians abroad and from Africans in the Diaspora. In this context, both President Jonathan and his predecessor President Yar' Adua have consistently expressed commitment to removing barriers to FDI in non-oil sectors. Though most FDI is still destined for the oil industry, the steps being taken under the reform agenda are bearing fruit.

On the other hand however, Babatunde et al (2013) in their study observed that the Nigerian Investment Promotion Commission (NIPC) has not been significant in attracting FDI into Nigeria. They attributed this to a set of factors inherent in Nigeria where NIPC operates and which might be impinging on its effective performance. They listed the factors to include the following:

$>$ The quality of country's investment environment and its growth rates -the larger the return perspectives to the investors, the larger there will be their investments. For this NIPC may be inefficient in case of unfavourable investment environment;

The scope of activities carried on by NIPC (including policy advocacy), the building of national image and the quality of support services offered to the investors;

$>$ The institutional links between NIPC and government managers-maintaining efficient mechanisms of relationships with policy makers (ministers and even the president in the case of a national agency) and the need to strengthen the commitment with NIPC's image.

On the basis of the above they recommended that NIPC should be given full autonomy in the administration of the numerous incentives in order to encourage the inflow of FDI into Nigeria, and 
secondly; Nigerian government should pledge their support by pursuing more credible, reliable and sound macroeconomic policies and provide conducive environment for FDI to flourish in Nigeria.

\section{Impact of FDI on Nigerian economy}

Generally, the literature on FDI and economic growth in general points to a positive relationship between the two variables and recommends few explanations for it. Standard determinants of economic growth include the rate of capital accumulation and variables that raise factor productivity, such as education level, institutional quality, macroeconomic stability, political stability and trade openness. In theory, economic growth may encourage FDI inflow when FDI is seeking consumer markets, or when growth leads to greater economies of scale and therefore increased cost efficiency. On the other hand FDI may affect economic growth through its impact on capital stock, technology transfer, skill acquisition or market competition. There are many empirical studies on the impact of FDI (Kurtishi-Kastrati, 2013).

"FDI has empirically been found to stimulate economic growth by a number of researchers (Borensztein et al., 1998; Glass and Saggi, 1999). Dees (1998) submits that FDI has been important in explaining China's economic growth, while De Mello (1997) presents a positive correlation for selected Latin American countries. Inflows of foreign capital arc (sic) assumed to boost investment levels" (Ayanwale, 2007: 31).

Researchers have tried to gauge the impact that FDI has on the Nigerian economy with mixed results. For example, Ehimare (2011) found out that FDI has positive and significant impact on current account balance in the balance of payment, but maintains that there is no strong empirical evidence to support the notion that FDI has been pivotal to economic growth in Nigeria. Ayanwale (2009) outlines various findings on this matter. Brown (1962) and Obinna (1983) report positive linkages between FDI and economic growth in Nigeria. Endozien (1968) discusses the linkage effects of FDI on the Nigerian economy and submits that these have not been considerable and that the broad linkage effects were lower than the Chenery-Watanabe average (Chenery and Watanabe, 1958). Oseghale and Amonkhienan
(1987) found that FDI is positively associated with GDP, concluding that greater inflow of FDI will spell a better economic performance for the country. Ariyo (1998) studied the investment trend and its impact on Nigeria's economic growth over the years. He found that only private domestic investment consistently contributed to raising GDP growth rates (public domestic investments were generally wasteful and had negative impact) during the period considered (19701995). Furthermore, there is no reliable evidence that all the investment variables included in his analysis have any perceptible influence on economic growth. He therefore suggests the need for an institutional rearrangement that recognizes and protects the interest of major partners in the development of the economy.

Kurtishi-Kastrati (2013) rightly observed that the world economy is changing very rapidly. Many countries in 60 s and 70 s were hostile toward foreign investment but as they realize the positive contribution foreign direct investment is making to their development their attitude toward FDI has changed. Stoneman (1975) analyzed the power of FDI on the economic growth of the developing countries and found that foreign investments increases the productivity levels due to higher capital stock and at the same time improves the balance of payment position. Ayanwale and Bamire (2001) assess the influence of FDI on firm level productivity in Nigeria and report a positive spillover of foreign firms on domestic firm's productivity. Ayanwale (2007) also observed that many countries and continents (especially developing ones) now see attracting FDI as an important element in their strategy for economic development. This he attributes mainly to the fact that FDI is seen as an amalgamation of capital, technology, marketing and management.

A lot of researches on the impact of FDI on the economy of host country vary in their findings depending on the focus and methodology of the research. But there appears to be a consensus that FDI impact on economic growth. Earlier researches favour short-run benefits, in which case the impact on economic growth appears not to be sustainable. For example, the following analysis by Kurtishi-Kastrati (2013) is instructive.

"Moreover, Kemp (1961) examined FDI and the advantages that the national economy receives from this type of external financing. According to 
Diamond (1965) the prospect of people in the countries which import capital is bright, and vice verse for people in the countries which export capital, their prospect is depressing. He placed special emphasis on the productivity of foreign investment. If not, the countries receiving it might not get real benefits. From these analyses or in other words from the early literature of the $1960 \mathrm{~s}$ it is revealed that in the short run the effect of foreign investment on economic growth are positive, but in the long run the benefits are not sustainable.

The effects of FDI regarding economic growth are examined for different regions. According to the date gained only Africa has improved its economic growth via FDI. However, the evaluations for other regions to confirm a positive relationship were not significant. Findlay (1978) verifies the influence of foreign investments on host country's technological progress rate, which takes place through a contagion effect involving factors employed by foreign firms such as more advanced technology and management practices. The impact of FDI with special reference to international trade was analyzed by Bhagwati (1978). According to him, countries actively pursuing an export led growth strategy can reap enormous benefits from foreign investment. Export led policy is one which connects average effective exchange rate on exports to the average effective exchange rate on imports. Whereas, import substitution policies are worked out in such a way that the two exchange rates are not equal. The previous policy favors free trade and emphasizes the need to boost export, while the latter underlines self-sufficiency through import substitution."

\section{RECOMMENDATIONS}

We would like to recommend the following in the light of the insight gained from this study.

1. Furtherance of economic growth and development is better achieved when the economic environment is favourable to business. Investors are more confident to put their resources where they have the relative assurance of a recoup. Consequently, we recommend that the investment climate should continue to be improved upon by all agencies of government.
2. Drawing from the above we suggest that the ongoing power sector reforms be carried to its logical conclusion in order to permanently settle the issue of power that has been a major bane of Nigeria's development.

3. We equally are of the opinion that the gains made in the areas of infrastructure enhancement by the outgoing administration of President Goodluck Jonathan should be built upon, and where there is need, to revise instead of scrapping and starting all over, as has notoriously been the case in the past.

4. A particular area foreign investors have been wary is the issue of multiple taxation. It is however gratifying to note that the coordinating minister of the economy has set machinery in motion to address this. We suggest that the reform in this area should be completed positively to make room for further external investment to flourish.

5. The Nigerian Investment Promotion Commission should be strengthened and granted greater autonomy for better functioning. The commission should therefore pay particular attention to improving the ease-of-doing-business posture of Nigeria.

\section{CONCLUSION}

For Nigeria, the impact of FDI on development is incontestable. The performance of the economy since the period of liberalizing the economy started shows much of this fact as can be attested by the observations that have been made above. For emphasis sake, Nigerian economy has been on the part of growth and when we consider the amount of foreign capital that has come in through the telecommunications sector, and recently, the power sector due to the power sector reforms, then it is safe to conclude that FDI is helping Nigerian economy to grow. This further explains the assertion we made earlier that Foreign Direct Investment helps to improve infrastructure development, and developed infrastructure would help attract further FDI into the economy. Thus we conclude with Olagunjoye (2010) that achieving true, meaningful and enduring development requires that government effectively tackle the challenges of basic infrastructural needs of the country by ensuring efficient, stable and reliable power supply, safe potable water, functional public transportation system, effective communication system, reliable health and educational facilities, good 
and environmentally-friendly public sanitation, and efficient security infrastructure.

\section{REFERENCES}

1) Abdel Gawad, G. M. \& Muramalla, V. S. R. (2013). Foreign direct investment (FDI) and its effects on oil, gas and refinery production and their exports: An applied study. Journal of Economics and Sustainable Development. 4(1). www.iiste.org.

2) Adejugbe, A. (2013). Foreign direct investment in Nigeria; Overcoming legal and regulatory challenges to foreign direct investments in Nigeria: Is Nigeria doing enough? Social Science Research Network.

3) Akanbi, N. N. (2010). Welcome Address On Investment Forum For The Strengthening Of Nigeria/Netherlands Relations And Sustainable Development Scheduled Held From 6th- 7th October, 2010 At The Rotterdam Chamber Of Commerce, Netherlands.

4) Akinwale, A. A. (2010). The menace of inadequate infrastructure in Nigeria. African journal of science, technology, innovation and development; 2(3),207-228.

5) Aitken, B. and Harrison, A. (1999). "Do Domestic Firms Benefit from Direct Foreign Investment? Evidence from Venezuela." American Economic Review, June 1999, 89(3), 605-618.

6) Ariyo, A. (1998). "Investment and Nigeria's economic growth". In Investment in the Growth Process Proceedings of Nigerian Economic Society Annual Conference 1998, 389^115, Ibadan, Nigeria.

7) Ayanwale, A. B. (2007). FDI and economic growth: Evidence from Nigeria. African Economic Research Consortium. AERC Research paper 165.

8) Ayanwale, A.B. and A.S. Bamire (2001). The Influence of FDI on Firm Level Productivity of Nigeria's Agro/Agro-Allied Sector. Final Report Presented to the African Economic Research Consortium, Nairobi.

9) Babatunde, K. A., Oyeniran, W. I., David, O. O. \& Ibrahim, W. (2013). Nigerian Investment
Promotion Commission and foreign direct investment in Nigeria. Kuwait Chapter of Arabian Journal of Business and Management Review.

10) Bergstrand, J. H., and Peter Egger. (2007) "A Knowledge-and-Physical-Capital Model of International Trade Flows, Foreign Direct Investment, and Multinational Enterprises," Journal of International Economics, 73(2): 278308.

11) Blonigen, B. A. \& Piger, J. (2011). Determinants of foreign direct investment. NBER working paper series, National bureau of economic research. January http://www.nber.org/papers/w16704.

12) Borensztein, E, De Gregorio, J. \& Lee, J. (1998). "How Does Foreign Direct Investment Affect Economic Growth?" Journal of International Economics, June 1998, 45(1),115-35.

13) Boyd, J. H. and Smith, B. D. (1992). "Intermediation and the Equilibrium Allocation of Investment Capital: Implications for Economic Development." Journal of Monetary Economics, 30(3), 409-32.

14) Brown, C.V. 1962. "External economies and economic development". The Nigerian Journal of Economic and Social Studies, 4(1): 16-22.

15) Caves, R. E. (1971): "International Corporations: The Industrial Economics of Foreign Investment", Economica, Vol. 38, pp. 1-27. In Protsenko, A. (2003). Vertical and horizontal foreign direct investments. Inaugural Dissertation, LudwigMaximilians- Universität, München.

16) Carr, D., Markusen, J. R., Maskus \& K. E. (2001) "Estimating the Knowledge-Capital Model of the Multinational Enterprise," American Economic Review, 91(3): 693- 708.

17) Chenery, H. B. and T. Watanabe. 1958. "International Comparisons of the structure of Production". Econometrica XXVI 487-521.

18) Contessi, S. \& Weinberger, A. (2011). Foreign direct investment, productivity and country 
growth: An overview. Federal Reserve Bank of St. Louis review, 91(2), 61-78.

19) Demirhan, E. \& Masca, M. (2008). Determinants of foreign direct investment flows to developing countries: A cross-sectional analysis. Prague Economic Papers.

20) Denisia, V. (2010). Foreign direct investment theories: An overview of the main FDI theories. European journal of interdisciplinary studies 2( 2).

21) Dinda, S. (2009). Factors attracting FDI to Nigeria: an empirical investigation. Madras School of Economics, Chennai, India.

22) Dunning, J. H. (1993). Multinational Enterprises and the Global Economy. Harlow, Essex: Addison Wesley publishing Co. in Demirhan, E. \& Masca, M. (2008). Determinants of foreign direct investment flows to developing countries: A cross-sectional analysis. Prague Economic Paper.

23) Endozien. E.G. 1968. "Linkages, direct foreign investment and Nigeria's economic development".The Nigerian Journal of Economic and Social Studies, 10(2): 119-203.

24) Ehimare, O. A. (2011). Foreign direct investment and its effect on the Nigerian economy. Business Intelligence Journal.4(2), 253 - 261.

25) Findlay, R. (1978). "Relative Backwardness, Direct Foreign Investment, and the Transfer of Technology: A Simple Dynamic Model." Quarterly Journal of Economics, . 1-16.

26) Feenstra, R. C. (1998): "Integration of Trade and Disintegration of Production in the global Economy", Journal of Economic Perspectives, 12(4), 31-50.

27) Feenstra, R. \& Hanson, G. H. (1997): "Foreign Direct Investment and Relative Wages: Evidence from Mexico's Maquiladoras", Journal of International Economics, 42, 371-394.

28) Leamer, E. E. (1996): "In Search for StolperSamuelson Effects on U.S. Wages", NBER Working Pape, 5036.

29) Hanson, G. H., Mataloni, R. J. Jr. \& Slaughter, M. J. (2003): "Vertical Production Networks in
Multinational Firms", NBER Working Paper, 9723.

30) Head, K. and Ries, J. (2008) "FDI as an Outcome of the Market for Corporate Control: Theory and Evidence," Journal of International Economics, 74(1): 2-20.

31) Ighodaro, C. (2009). Transport infrastructure and economic growth in Nigeria. Journal of research in national development 7(2). http://www.ajol.info/index.php/jorind/article/view 150973

32) Kozenkow, J. ( ). The pros and cons of foreign direct investment international businesses. http://smallbusiness.chron.com/pros-cons-foreigndirect-investment-international-businesses56164.html.

33) Krugman, P. (1996): "Does Third World Growth Hurt First World Prosperity?", Harward Business Review, 72,. 113-121.

34) Kurtishi-Kastrati, S. (2013). Impact of FDI on economic growth: An overview of the main theories of FDI and empirical research. European Scientific Journal; March 2013 edition .9 ISSN: $1857-7881$.

35) Lankes, H. \& Venables, A. (1997): "Foreign direct investment in economic transition: the changing pattern of investments", Economics of Transition, Vol. 4(2), pp. 331-347.

36) Markusen, J. R. (1995): "The boundaries of multinational enterprises and the theory of international trade", Journal of Economic Perspectives, 9(2), 169-189.

37) Markusen, J. R. \& Venables, A. (1997): "Foreign Direct Investment as a catalyst for industrial development", European Economic Review, 43, 335-356.

38) Nigeria Sovereign Investment Authority. Infrastructure fund investment policy statement. Retrieved from http://nsia.com.ng/nigeriainfrastructure-fund/.

39) Obinna, O.E. (1983). "Diversification of Nigeria's external finances through strategic foreign direct investment". Nigerian Economic Society Annual Conference Proceedings, Jos, 13-16th. 
40) Odozi, V.A. (1995). An Overview of Foreign Investment in Nigeria 1960-1995. Occasional Pape No. 11. Research Department, Central Bank of Nigeria.

41) Oladunjoye, P. (2010). "Infrastructure bane of development". Daily Independent (online). http://dailyindependentnig.com/2013/10/infrastruc ture-bane-of-industrial-development/ retrieved on 21 March 2015.

42) Oseghale.B.D. and E.E. Amonkhienan. 1987. "Foreign debt, oil export, direct foreign investment (1960-1984)". The Nigerian Journal of Economic and Social Studies, 29(3): 359-80.

43) Protsenko, A. (2003). Vertical and horizontal foreign direct investments. Inaugural Dissertation, Ludwig-Maximilians-Universität, München. Retrieved from: edoc.ub.unimuenchen.de/2105/1/Protsenko_Alexander.pdf , March 17, 2015.

44) Rivera-Batiz, F. and Rivera-Batiz, L. (1991). "The Effects of Direct Foreign Investment in the Presence of Increasing Returns Due to Specialization." Journal of Development Economics, November 1991, 34(1-2), 287-307.

45) Sichei, M. M. \& Kinyondo, G. (2012). Determinants of foreign direct investment in Africa: A panel data analysis. Global journal of management and Business Research. 12(18) 